\title{
The Development of Fiqh Munākahah (Marriage Jurisprudence) Material Course in Madurese Islamic Universities and Its Relation with Gender Equality and Divorce Prevention
}

\author{
Maimun \\ Faculty of Shariah IAIN Madura, Jl. Raya Panglegur km. 4 Pamekasan 69371 \\ Email:maimun@iainmadura.ac.id \\ Ainul Haq Nawawi \\ Faculty of Tarbiyah IAIN Madura, Jl. Raya Panglegur km. 4 Pamekasan 69371 \\ Email:haqainul@ymail.com \\ Abdul Haq Syawqi \\ Faculty of Shariah IAIN Madura, Jl. Raya Panglegur km. 4 Pamekasan 69371 \\ Email: asyawqi@iainmadura.ac.id
}

Article history: Received: 20 November 2019, Accepted: 24 October 2020, Published: 28 December 2020

\begin{abstract}
:
Explanation of Law 1/1974, number 4 point e, obviously accentuates the principle of complicating divorce. It requires specific reasons beyond the lawsuit and, in line with article 115 of KHI (Kompilasi Hukum Islam; Islamic Compilation Book), obliges the process to take place in the court trial. This implies that divorce needs prevention from the whole parties both persons and institutions, including Islamic universities. Islamic universities have both academic and social responsibilities to prevent divorce due to their strategic duties and function in community development and empowerment, specifically for spreading knowledge. This research aims to identify how far Madurese Islamic universities perform their roles and function by designing fiqh munākaḥah (marriage jurisprudence) materials for students as prospective husbands and wives. It focuses on
\end{abstract}


whether the materials get developed and are compatible with gender equality and divorce prevention efforts. Using a qualitative approach particularly its phenomenological type, this study took place in three Madurese Islamic universities. It revealed that the latest development of fiqh munākahah materials are still mostly about the normative perspective from classical fiqh literature with very little relevances to either gender equality spirit or divorce prevention effort.

\title{
Keywords:
}

Fiqh Munākaḥah; Madurese Islamic Universities; Gender Equality; Divorce Prevention

\begin{abstract}
Abstrak:
Penjelasan UU Nomor I Tahun 1974, angka 4, huruf e, jelas menekankan prinsip untuk mempersukar perceraian dengan mewajibkan alasan-alasan tertentu serta, senada dengan KHI Pasal 115, mengharuskan proses perceraian terjadi di depan sidang pengadilan. Ini menunjukkan bahwa tugas mencegah perceraian harus dilakukan siapapun, baik perorangan ataupun instansi, termasuk Perguruan Tinggi Islam. Perguruan Tinggi Islam memiliki tanggung jawab akademik dan sosial karena tugas dan fungsinya yang strategis dalam pengembangan dan pemberdayaan masyarakat, terutama dalam penyebaran pengetahuan. Untuk mengetahui sejauh mana Perguruan Tinggi Islam di Madura menjalankan peran dan fungsinya tersebut, penelitian ini menelusuri kajian figh munäkahah sebagai bahan konsumsi bagi calon-calon suami dan istri, khususnya apakah materi-materi tersebut sudah berkembang dan sesuai dengan wacana kesetaraan gender dan upaya pencegahan perceraian. Menggunakan pendekatan kualitatif berjenis fenomenologis, penelitian ini mengambil setting di 3 Perguruan Tinggi Islam di Madura. Hasil penelitian menunjukkan bahwa perkembangan terbaru kajian figh munākahah masih didominasi kajian normatif dari sumber figh klasik sehingga belum relevan dengan semangat kesetaraan gender maupun upaya pencegahan perceraian
\end{abstract}

\section{Kata Kunci:}

Fikih Munākaḥah; Universitas Islam Madura; Kesetaraan Gender; Pencegahan Perceraian 


\section{Introduction}

In recent years, the number of divorces increases at both local and national levels. Last November 2016, for instance, there found 315.000 divorce cases registered at the whole Indonesian Religious Court and Supreme Court. ${ }^{1}$ The number consists of both judicial divorces in which the case was filed by a wife and repudiation or divorce from a husband's initiative.

Interestingly, the judicial divorce cases were higher in number than the repudiation numbering 224.240 received reports. 152.395 of them were legally divorced by the Religious Courts while the rest varied, ranging from submission withdrawal, rejection, unaccepted submission to removal from the registration. Whereas, repudiation divorce had a fewer number about 90.000 cases with $60 \%$ accepted cases. The number still excluded the cases sentenced by the State Court. $^{2}$

Furthermore, three provinces in Java were identified as the top three regions in contributing the number of divorce cases, namely Central Java, East Java, and West Java. In East Java itself, the Religious Courts of Sampang and Pamekasan contributed mostly to judicial divorce case numbers. This type of divorce became a new trend among the married couples in those two districts which then led to the increasing divorce number. Pamekasan Religious Courts on 2014/2015 recorded divorce cases numbering 496 and judicial one with 766 cases. The number of cases exceeded in Sampang with 1.037 judicial divorce cases and 782 divorce cases. ${ }^{3}$ The numbers increased significantly in the following years, specifically at Sampang Religious Court.

Some previous research show that the increasing number of divorce cases were due to both internal and external factors. The internal factor, they mentioned, closely relates to inadequacy of

\footnotetext{
1Liputan6.com, "Divorce Cases," 17th November, 2016, https:// www.liputan6.com/news/read/2654870/224-ribu-istri-di-

indonesia-ceraikan-suaminya-selama-2016.

${ }^{2}$ Liputan6.com.

${ }^{3}$ Harian Terbit, "Talaq Divorces," Mei 29th, 2015. Accessed on April 3 $3^{\text {rd, }}$ 2017. Compare to Radar Madura, "Talaq Divorce," May 2th, 2015.
} 
education in which most of women divorcees graduated from primary school while the men were from secondary school. This factor might indirectly trigger the number, but in reality, intellectual, spiritual and emotional intelligence, skill, as well as conceptual capability about marriage really matter. Available working opportunities, furthermore, are also in line with educational level which then influences the economic prosperity of a household.

Meanwhile, the external factor is clear from the high accessibility of the court as a part of the public service facility in addition to the third party's contribution and support from both relatives and local public officials. The religious teaching, on another hand, makes it possible for either wife or husband to file for a divorce lawsuit. This gets worsened by ineffective pre-married education by the Ministry of Religious Affair with outdated materials, old methods, boring learning strategies, and unsupportive learning venues. ${ }^{4}$

Sufficient conceptual understanding of marriage life is believed to significantly contribute to the household's integrity. Any household will certainly and inevitably cope with both sweet and bitter moments as a common natural circle. A couple with good conceptual maturity in the marriage itself can likely survive and go through both moments. Therefore, content or material in marriage conceptual lesson becomes an important theme to discuss, mainly about the relation among the ontology of marriage, task and responsibilities of each, balanced right and obligation between both spouses, equality in role and function according to the recent necessity of modern family and so forth.

Base on it, rearrangement of figh munākahah (marriage jurisprudence) lesson is necessary particularly to identify its relevancy with current development and reality. However, it needs participation from several parties out of the Ministry as the publisher of the marriage handbook. Islamic boarding schools (pesantren) and universities are also supposed to actively participate due to their main role and responsibilities to the public. At least, they can contribute

\footnotetext{
"Maimun; Muhammad Thoha, "Fenomena Cerai Gugat dan Wacana Kesetaraan Gender (Studi Alasan di balik Trend Kasus Cerai Gugat di Pengadilan Agama Kabupaten Sampang dan Pamekasan Madura)" (Pamekasan, 2017), 147.
} 
any insight in formulating the curriculum to produce fair and equal content based material lessons.

Relating to that, this research wants to portray how three Madurese Islamic Universities developed their figh munākahah materials. It focuses on the issue of gender equality and the effort to reduce divorce rate through the following steps; Firstly, it describes the profile of figh munäkahah materials of the universities. Secondly, it describes the development procedure of the materials. Thirdly, it describes the feasibility level of fiqh munäkahah materials at the universities as a part of divorce prvention effort.

\section{Method}

This research used qualitative approach which according to Bogdan and Taylor, resulted in descriptive data either written or spoken from observed subject and its behavior. ${ }^{5}$ On the other hand, Kirk and Miller explained that qualitative research is a specific convention in the social study which fundamentally depends on human's observation and relates to them in terminological field. ${ }^{6}$ The qualitative research furthermore puts its basic concern on phenomenology by observing people's behavior as the result of the way they predict and understand the world. ${ }^{7}$

Accordingly, this is also field research as clear from its characteristic to accentuate research object on people, event, setting and document. In this type of research, each object will be comprehensively examined and observed according to their background and context to understand various relationships among its variables. ${ }^{8}$

This research itself took place in three Madurese Islamic universities namely IAIN Madura (located in Pamekasan), INSTIKA

${ }^{5}$ Lexy J. Moleong, Metode Penelitian Kualitatif (Bandung: Remaja Rosdakarya, 2005), 4.

${ }^{6}$ Suharsimi Arikunto, Prosedur Penelitian, Suatu Pendekatan Praktik (Jakarta: Rineka Cipta, 2002), 2.

7Robert Bogdan; Steven Taylor, Dasar-Dasar Penelitian Kualitatif, transl. A. Khozen Afandi (Surabaya: Usaha Nasional, 1993), 44.

${ }^{8}$ Imron Arifin, ed., Penelitian Kualitatif dalam Ilmu-Ilmu Sosial dan Keagamaan (Malang: Kalimas Sahada, 1997), 57. 
Guluk-Guluk (located in Sumenep), and UIM (located in Pamekasan). The three are deemed representative of two Madurese districts, namely Pamekasan and Sumenep. Additonally, they are quite popular in Madura Island and its surroundings so that every year, they admit a thousand of university students.

Researchers came to the locations serving various roles ranging from observers, interviewers, data collectors, as well as participants. During the visit, researchers got along with research subjects without any space or distance. Therefore, occasionally, research subjects did not recognize the researchers' purpose even existence that enables us to obtain real and objective data.

The data source of this research is divided into two, namely human and non-human. Human category consists of figh munäkahah lecturers, university rectors, students, and other related parties. Meanwhile, the non-human sources are relevant documents, books, news, SAP (learning plan details) and RPS (semester learning plan) of the subject, module of the subject, and students' worksheet. Meanwhile, as the characteristic of qualitative approach, data were collected commonly through observation, interview, and documentation complying with standard data procedure to ensure its quality. ${ }^{9}$

As the next step, data analysis of this research uses three following steps: First is data reduction consisting of arrangement on the obtained data systematically then highlighting the main problems and findings to get the data reduced or shortlisted. Second is data displaying through simplifying abundant data by the use of model, mapping, table, and diagram to get it clustered into relevant details. Third is data heuristic by discovering both differences and the similarities found in the data then comparing the interrelated themes.

The Profile of Fiqh Munākaḥah Course Material at Madurese Islamic Universities

Identifying profile of figh munākahah course materials at Madurese Islamic universities becomes crucial considering that it influences effectiveness of the learning process itself. Moreover, it is 84.

9Sumadi Suryabrata, Metodologi Penelitian (Jakarta: Rajawali Press, 1992), 
typically set under systematic arrangement in either written form or not. It consists, at least, of cognitive, skill, and behavior based material which requires students to accomplish the outlined competencies through the detailed learning themes. ${ }^{10}$

In determining the theme as well as the series, lecturers usually rely on each institution's curriculum and syllabus. In the context of figh munäkahah, the theme is usually classified into three. First is basic concept of marriage namely definition, purpose, advantage, related law and its authority, principles, as well as the right and obligation of the married couple. Second is the reason for divorce and related solution such as nushūz (recalcitrant), shiqāq (irresolvable family dispute), hakamayn (two peacemakers from both parties), 'iddah (waiting period), and rujü' (reconciliation). Third is about polygamy and its problems. Recent problems such as early marriage, interfaith marriage, and other issues are also included. ${ }^{11}$

Systematically, the series of theme is already appropriate with outlined competency standard (cognitive, affective, and psychomotor) as well as reliability test. The scope of themes is also adjusted to students' necessities as a part of society. This also aims to attract their interest in learning fiqh munäkahah so that the learning goals and expected competencies can be easily achieved. Therefore, learning materials must be systematically ordered and complete consisting of its suitable delivery method, rule, and evaluation procedure. ${ }^{12}$

In a closer look, it becomes clear that the course starts from the easiest and the most basic concept to more difficult one which requires the most attention, such as solving any household conflicts. Meanwhile, the material presentation is generally by lecturing method then assigning students to investigate the problem in surrounding society so that they can integrate it along with their

${ }^{10}$ Ali Mudlofir, Aplikasi Pengembangan Kurikulum Tingkat Satuan Pendidikan dan Bahan Ajar dalam Pendidikan Agama Islam (Jakarta: Rajawali Press, 2011), 184.

${ }^{11}$ Masyhuri, "The Lecturer of Figh Munakahah Subject, Department of Islamic Religious Education, INSTIKA Guluk-Guluk Sumenep, direct interview on March 24th, 2018."

${ }^{12}$ Ika Lestari, Pengembangan Bahan Ajar Berbasis Kompetensi (Padang: Akademi Permata, 2013), 1. 
theoretical understanding. This combination is among those which influence students' interest on the material because it reflects surrounding realities, relates to their future life and directly affects their personality. ${ }^{13}$

However, this does not mean that students must directly practice the marriage by themselves. Instead, they are required to observe how society build the marriage relationship by comparing between harmonious and broken marriages. Getting figh munākahah materials cognitively and practically furthermore means a lot for them to get comprehensive understanding on marriage from its various aspects. Additionally, they can get lesson learned to apply for the future family they are going to build because establishing an imperishable marriadge requires adequate knowledge.

Sending students to directly observe and interact with society also enables figh munākahah lecturers to correct any common misleading understanding about marriage through students. For example, some people still consider engaged couple the same as marriage couple that it leads to some unexpected condition such as adultery and illegal pregnancy. If this remains the same and those people do not get any right and comprehensive explanation, problems will remain hard to solve even lead to other further problems.

Meanwhile, most of references in fiqh munäkahah course refer to figh books by big schools' Islamic scholars ('ulamä' madhhab) specifically those affiliated to ahl al-sunnah. ${ }^{14}$ However, some lecturers mentioned that those references have been less relevant to Indonesian contemporary development. They mentioned some sampling themes namely the meaning and essence of marriage, forced marriage for women, inequal right and duty of wife under husband's authorities in any circumstances, the concept of breadwinner, polygamy, age limitation for marriage, and others that are hard to apply in Indonesian nowadays context. Consequently, they need to conduct

\footnotetext{
${ }^{13}$ Abdul Jalil, "The Lecturer of Fiqh Munakahah Subject, Department of Islamic Family Law, IAIN Madura, direct interview on April 3rd, 2018."

${ }^{14}$ Ainul Haq, "The Lecturer of Munakahat Fiqh in Islamic Religion and Education Department of Tarbiyah Faculty IAIN Madura, Direct Interview on March 22nd 2018."
} 
deeper analysis on those old references while integrating them with contemporary based references. ${ }^{15}$

On the essence and meaning of marriage, for instance, the old jurisprudents of the four big schools of law defined it as a process towards legalization of cuddling or sexual relations (istimt $\bar{a}$ ') between men and women. They base their definition from this literal meaning referring to intercourse, gathering, and the likes. Hanafiyah scholars defined marriage as a contract which is advantageous for intentional joy-sharing, ${ }^{16}$ while Hanäbilah scholars defined it as a contract with the concept of inkah which means tajwiz referring to taking benefits for fun. ${ }^{17}$ Accordingly, Shäfi'iyah scholars provide a literal based definition, namely the contract which legalizes sexual relations between men and women. ${ }^{18}$

Certainly, delivering these definition for students in doctrinaltextual manner will greatly affect their understanding. They will likely consider that marriage only aims to justify and legalize sexual relationship without any concern on responsibility, rights, obligation, and so on. Therefore, it is necessary to reformulate the concept of marriage so that it will not lead to any narrow understanding in both society and students. Apart of it, the lecturers are still obliged to deliver definition of old scholars as students' basic knowledge while accentuating a more comprehensive perspective on the definition. Marriage, for example, can be defined as a gateway to get peaceful life with full of love and affection, responsibility of each and one another, and so forth.

The lecturers engaged of this research are all aware of this misleading potency so that in delivering materials, they combine those two concepts. While mentioning old concept of classical Islamic scholars which tend to put women as objects with men as the subjects,

15 Jalil, "The Lecturer of Munakahat Fiqh in the Act of Islamic Family Department Syari'ah Faculty of IAIN Madura, Direct Interview on April 3rd 2018." Compare with Ahmad Farid Mawardi, "The Lecturer of Munakahat Fiqh in Islamic Religion Faculty of UIM Pamekasan, Direct Interview, May 3rd 2018."

16`Abd al-Rahman Al-Jazīrī, Al-Fiqh 'Ala Al-Madhāhib Al-Arba'ah, 4th ed. (Beirut: Dar al-Kutub al-Ilmiah, 2003), 3.

${ }^{17}$ Al-Jaziri, 4.

${ }^{18}$ Al-Jazīrī, Al-Fiqh 'Ala Al-Madhāhib Al-Arba'ah. 
they offer newer concept of marriage by current conditions. For instance, they stress in delivering materials on the fulfillment of both right and obligations for husband and wife fairly and proportionally manner. They believe that this must be well developed and promoted to change society's mindset on rights and obligations of husband and wife. ${ }^{19}$ A lecturer mentioned that he liked to deliver the concept of marriage as a contract which aims to build an eternal and lifetime household. Therefore, it needs strong foundation by having well knowing each others as it will lead to mutual understanding, mutual commitment for each right and obligation, as well as continual fostering on peace, love and affection. ${ }^{20}$

\section{Development of Fiqh Munākaḥah Material Course with Gender Equality Issues}

Developing course material is among the lecturers' obligations and responsibilities. Normatively, the duties of lecturers are explicitly stipulated in the regulations of the Minister of Research, Technology, and Higher Education, which reads: "Lecturers are professional educators and scientists with the main task of transforming, developing, and disseminating science and technology through education, research, and community service" ${ }^{21}$

Regarding that, lecturers in the three Madurese Islamic universities have already done so. They have all developed material courses in both written form such as textbooks or lecture modules and

19 Masyhuri, "The Lecturer of The Act of Marriage Subject Islamic Religion and Education Department of INSTIKA Guluk-Guluk Sumenep, Direct Interview on March 24th 2018."Jalil, "The Lecturer of Munakahat Fiqh in the Act of Islamic Family Department Syari'ah Faculty of IAIN Madura, Direct Interview on April 3rd 2018."Mawardi, “The Lecturer of Munakahat Fiqh in Islamic Religion Faculty of UIM Pamekasan, Direct Interview, May 3rd 2018."

20 Jalil, "The Lecturer of Munakahat Fiqh in the Act of Islamic Family Department Syari'ah Faculty of IAIN Madura, Direct Interview on April 3rd 2018."

$21^{\prime \prime}$ Decree of Minister of Riset, Technology, and Higher Education in the Republic of Indonesia Number 2 in 2016 about the Amandement of Ministerial Decree Number 26 in 2015 about Lecturer's Registration in Higher Educational Institute Subsection 1" (2016). 
unwritten ones when explaining the topics of discussion. Course materials themselves can be in printed version, audio, audio-visual, as well as interactive one such as digital. ${ }^{22}$ Nevertheless, it is out of this research's scope to analyze the form of course materials. What is important here is the way the lecturers develop their course material, the foundation of its development and delivery methods.

Data from interviews, observation and document analysis shows that figh munākahah lecturers have developed the course material following the procedures in their respective institutions. They adjust the material to the aims and targets of the course while the level of breadth and depth of study and the mapping are made in line with the procedures of the university curriculum. More specifically, the development they make is clear from the description of the courses contained in the semester learning plan. This plan will then be explored in details of learning activities as needed.

One of the things that lecturers considered in developing the course material is the need of students as a part of society. For instance, they review the concept of the marriage essence and meaning that encourages strong and harmonious relationships. To fulfill this need, lecturers do not only introduce the concept and essence of marriage normatively, but also elaborate it by telling and analyzing family figures of prophets, companion, and scholars who were successfull in fostering eternal households. Those figures can therefore be role models for students and society in general.

The development of the course material is also a subject to adjust to the recent contemporary situation particularly with its social change. Social change requires changes in other related things, including the law. In this case, Islamic family law must carry out its function as a law to be compatible as both social control and Moslem's guidance. Specifically to figh munäkahah, it needs to be the firm law on the one hand while flexibly responsive to social change on the other hand. In other words, it is neither rigid nor permanent in any case and situation. Instead, it is open for any review, reformation, modification, and such with considerable argument due to the basic values of 174.

${ }^{22}$ Abdul Majid, Strategi Pembelajaran (Bandung: Remaja Rosdakarya, 2013), 
justice and people's benefit. This becomes urgent to consider as a truth of law is relative, as well as those of scientific theories. ${ }^{23}$

Moreover, to fulfill basic requirements and principles as good course material, it needs to be contextual with society's real needs and conditions. This means that the material needs to reflect society's situation so that students can easily relate it with their surrounding phenomenon. Relevance to the recent phenomenon also makes them easier in finishing any assignment as a part of the learning method. ${ }^{24}$

It is also interesting to note that the lecturers rely the course material development on the spirit of justice and gender equality. They typically design specific discussion on this issue in several meetings or make it included in the discussion of each meeting as the mainstream perspective. ${ }^{25}$ This makes so much sense because the course material of figh munākahah mostly talks about family law, specifically about the behavior of husband and wife in the household.

One of the most relevant discussion themes with the gender equality perspective is on duties and responsibilities of a husband and wife in a household. This theme used to be gender-biased, antiequality, and portraying mindset which puts the husband in a superior position while the wife is the inferior one. At worse, this theme often reduces or exploits women's rights in a family. ${ }^{26}$

Other related themes are found fragile to promote gender injustice relationships in a family, such as the wife's obligation to obey her husband in any situation and her obligation to get the husband's consent for doing any uncompulsory worship such as sunnah (uncompulsory) fasting. Old course material of fiqh munākahah liked to cite a hadith narrated by al-Bukhārī-Muslim literally mentioning the prohibition for a wife to do uncompulsary fasting when her husband does not allow her. It reads, "don't let a wife fast for a day while her

${ }^{23}$ Masyfuk Zuhdi, Masail Al-Diniyah Al-Ijtimaiyah (Jakarta: Gunung Agung, 1993), 177.

${ }^{24}$ Chomsin S Widodo and Jasmadi, Panduan Menyusun Bahan Ajar Berbasis Kompetensi (Jakarta: PT Elex Media Kompetindo, 2008), 50.

${ }^{25}$ Mawardi, "The Lecturer of Munakahat Fiqh in Islamic Religion Faculty of UIM Pamekasan, Direct Interview, May 3rd 2018."

${ }^{26}$ Masyhuri, "The Lecturer of Figh Munakahah Subject, Department of Islamic Religious Education, INSTIKA Guluk-Guluk Sumenep, direct interview on March 24th 2018." 
husband is at home except with his permission, except for Ramadhan fasting".

In fact, Islamic scholars are different in responding to this hadith. Some of them, with textual interpretation, assumed that fasting is forbidden for a wife unless her husband allows it. This is valid for the compulsory fasting and when the husband is staying at home. Some others mentioned that a wife can do uncompulsory fasting without her husband's permission as long as it does not interrupt his right. Therefore, although a husband allows his wife for fasting it makes her neglecting the husbands' rights, she will still have sinned. 27

Although look quite different, those two opinions are genderbiased and ignoring the justice values. It implies husband's absolute authority over his wife even in the matter of worship. This is certainly very contrary to Islamic concept which teaches independence of each individual in doing worship without any gender discrimination. Moreover, it is only valid for wife and not otherwise.

Another fragile theme in the course implying gender injustice is the concept of guardianship which has been, again, the absolute authority of men. If a father of a bride is still alive, he will become the guardian. If he passes away or unavailable for serving the role, the guardianship rights will turn to other male family members such as grandfather, brother, uncle and so on. The majority of Islamic scholars believe that guardian is one of the marriage pillars and because the brides are women, either girls or widows, the guardians must be men. ${ }^{28}$ As a consequence, women cannot be any marriage guardian for another woman.

A lecturer of figh munäkahah mentions that he likes to discuss this specific theme in his class using the perspective of gender equality. ${ }^{29} \mathrm{He}$ usually relates it to other guardianship requirement outside the marriage contract such as in reconciliation, divorce, and so on. However, he stressed that he always said at every early step of

27Sofyan \& Zulkarnain Suleman, Fikih Feminis Menghadirkan Teks Tandingan (Yogyakarta: Pustaka Pelajar, 2014), 89.

${ }^{28}$ Suleman, 103.

${ }^{29}$ Jalil, "The Lecturer of Figh Munakahah Subject, Department of Islamic Family Law, IAIN Madura, direct interview on April 3rd 2018." 
discussion that the majority of (old) Islamic scholars, or so called jumhūr 'ulamā, assume that it is illegitimate for women to be the witnesses because the legal requirements for witnesses must be two men. ${ }^{30}$ He then compares this to al-Hanafi school, a well-known rational jurisprudence school, which allows women's witnesses even though two women are counted the same as a man. Therefore, two witnesses (shähidayni) according to the Koran counts four women witnesses.

The last most striking household theme which also tends to be gender biased is girls' authority to decide their future partners. It turns out that the lecturers are aware of this so that they have included this theme in the course material they arrange and develop in their respective universities. Some of them, for example, also explained that Abu Hanifah had relatively different opinion from the rest in which, according to him, a growing up girl (bälighah) may decide their future partner independently. Moreover, he thought that she, either girl or widow, might also make their marriage contract as long as the spuose is commensurate $\left(k u f \bar{u}^{\prime}\right.$ or in line with her in various aspects) and able to afford the common local dowry (mahr mithil). ${ }^{31}$

However, they do not only deliver the opinion of Abu Hanifah without the reason or context beyond. They generally explain that the opinion which allows women to choose their own partner is based on consideration that it is her who will go through her own married life. Times have changed a lot of things along with fast development of science and technology and globalization tide that it demands people to rethink about what they used to thought and had opinion about.

\section{The Feasibility of Fiqh Munākahah Material Course to Prevent Divorce Cases}

Universities or tertiary institutions with religious faculties do not only have academic roles, but also social responsibilities to foster and develop the community. Through the implementation of higher education's tri dharma, those universities find their space for

\footnotetext{
${ }^{30}$ Al-Jazīrī, Al-Fiqh 'Ala Al-Mazahib Al-Arba'Ah, 23-24.

${ }^{31}$ Muhammad Ibn Ali al-Hanafī al-Haskafī, Al-Durr Al-Mukhtār, 3rd ed. (Beirut: Dar al-Kutub al-Ilmiyyah, n.d.), 64.
} 
accomplishing the mission. They carry out education and learning processes for students, promote research and development for the academic circle, and devote lecturers as well students for community service. For the last mission, they greatly help resolve existing social issues, including divorce cases which the current numbers are increasing day by day.

In this context, to prevent the increasing number of divorce rates in Madura, Madurese universities have a very crucial and vital role. PTKI based universities have much more responsibilities than general tertiary institutions given their "Islam" label attachment although on the other hand, general universities are also trying to promote Islamic studies in the integration with social sciences. ${ }^{32}$ They are supposed to be a center for brainstorming agenda and development of Islamic mission not only among students, but also for Moslem society in general. ${ }^{33}$ Accordingly, they have much more chance to accomplish this mission due to their human resources' expertise in Islamic studies with relevant curriculum and courses.

Therefore, one of the real actions that universities can do for coping with this situation is to develop relevant course materials with proper content, method and approach. They must formulate feasible course materials to prevent divorce which society can easily apply. Fiqh munākahah course is among the most highlighted points that lecturers and universities need to pay much attention to not only because it is a part of Islamic law in mu'āmalah (human interaction) scope, but also due to its urgencies for students and society.

Appropriate and feasible figh munäkahah materials should contain materials that complicate or discourage the divorce process without impressing any prohibition. It also needs practical exposition, not merely a therotical one. Unfortunately, the course materials of those three universities are found not quite feasible to support the mission. This is clear from references in which most of them come from scholars of old jurisprudence schools. There only found a few lecturers who explicitly mentioned contemporary references from

32Rafi'ah Gazali, "Tradisi Keilmuan Islam di Perguruan Tinggi Umum; Suatu Tinjauan Di Bidang Hukum Islam dan Pranata Sosial," Ijtimaiyya 6, no. 1, February (2013): 98.

33Ishomuddin, Spektrum Pendidikan Islam (Malang: UMM Press, 1996), 81. 
modern thinkers even as secondary sources. It appears that figh munākahah course material is still not feasible enough to contribute to minimizing high rate divorce cases in Madura, especially in Pamekasan and Sumenep Regencies. Neither have they provided a solution for coping with the phenomenon.

A few lecturers are even still hesitant to walk out from authority or hegemony of classical scholars about the concepts and essence of marriage, equal rights and obligations between husband and wife, as well as other issues which so far are viewed by textual approach. The textual approach often leads to difficulties even threatens the relevance of Islamic law in responding to the recent challenges and current social change. It furthermore closely relates to the characteristic of classical figh which centered on one particular school with narrow mindset while ignoring society's living law..$^{34}$

However, it is important to note that in the sense of learning method, lecturers have used proper delivery technique which does not only rely on cognitive knowledge. They equipped students with technical skill to solve real problems they likely deal with in the real life through continual and gradual training. This makes them ready and accustomed to cope with complicated society problem and challenge.

This then comes as an irony considering that actually, those lecturers support the concept to complicate divorce process. ${ }^{35}$ However, they are not brave enough to leave classical jurisprudence references. The best thing that they can do is by developing delivery methods to make students understand that permissibility for divorce is not valid for any situation. They tell students that the permission for divorce shouldn't be understood in haqiq $\bar{i}$ or absolute way. Instead, it needs majāzi (contextual) interpretation because the better choice is avoiding divorce and maintaining the marriage when it is possible.

Additionally, they intensively equip students with tips for finding a good and proper partner according to Prophet's guidance which prioritizes religious aspect. This is deemed important because

${ }^{34}$ Muhammad Jayus, "Menggagas Arah Baru Studi Hukum Islam di Indonesia," Al-'Adalah XI, no. 02 July (2013): 261.

${ }^{35}$ Mawardi, "The Lecturer of Figh Munakahat Subject in Faculty of Islamic Religion, UIM Pamekasan, direct interview, May 3rd 2018." 
criteria for a future spuose will determine the process to build sakinah (peaceful), mawaddah (full of love) and rahmah (merciful) household. Another strategy that the lecturers used is identifying some common causes of divorce, such as polygamy. They accentuated that polygamy is not a suggestion to do. Instead, it is only allowed under very strict requirements which is almost impossible to fulfill without breaking any rule. ${ }^{36}$ A lecturer even mentioned that instead of building a sakinah, mawaddah and rahmah household relationship, polyamy is destructing the household.

Another common cause of divorce is early marriage. This also becomes one of issues that lecturers mentioned in class discussion particularly about its disadvantages. Furthermore, they also explored some causes that make this practice popular, ranging from parental low understanding on the marriage purpose, illiteracy on reproductive health to minimum awareness on physchoogical and physical threats on the children. ${ }^{37}$ Early marriage is also believed to be triggered by very rushed decisions in resolving dating relationship problems among teenagers. These all show that indirectly, lecturers have taken part in preventing divorce in their surrounding environment although this still needs much more improvement and follow-up steps.

For instance, the course material of figh munäkahah needs serious review and development so that it can guide the public into new perspective in dealing with contemporary problems. For instance, early marriage should not always be solution for any adolescent problems such as dating relationship or free sex. Review and improvement of the course material will provide more complete understanding on both concept of marriage and related problems, including those that adolescence deal with, such as regarding with the importance of maintaining reproductive health. It will be very

${ }^{36} \mathrm{Haq}$, "The Lecturer of Figh Munakahat Subject, Department of Islamic Religion Education, IAIN Madura, direct interview on March 22nd 2018."

${ }^{37}$ Masyhuri, "The Lecturer of Figh Munakahat Subject, Department of Islamic Religion Education, INSTIKA Guluk-Guluk Sumenep, direct interview, on March 24th 2018." 
reasonable to include materials on the awareness of reproductive health for children and teenagers at the course material. ${ }^{38}$

Moreover, formulating contextual and applicable course materials require a variety of discussions and perspectives, including gender equality on both right and obligation of each spuose. It also needs to accentuate that marriage is not merely to justify an intimate relationship, but rather to build a strong bond in building an eternal family with the proportional concept of division of labor. This becomes possible when all lecturers expand their insight and the discussion models while being brave to move from doctrinairenormative point of view to non-doctrinaire-sociologists one or from textual understanding to contextual ones.

This certainly does not mean randomly or irresponsible contextual way of thinking without considering the type of normative text either it is thawābit (constant, unable to change) or mutaghayyirāt (flexible, a subject to change). Instead, it is more about how to find proper ways to treat the texts proportionally according to balanced or moderate methodological corridors which are neither right nor left extremes. Moderate figh munäkahah means figh which seeks to combine literary comprehension of the text and maquassid al-sharī'ah. ${ }^{39}$

Another characteristic of moderate figh munäkahah is its concern to the aspects of the times, technology, and recent development of society's life. This is mainly because the study of Islamic law in any tertiary institutions is suppossed to be responsive for dynamic needs of Muslim communities both at the local and global levels. ${ }^{40}$ To make this comes true, Islamic universities, to be more specific, needs to make themselves as centers of study which continuously update epistemological concepts and knowledge to provide relevant understanding among Muslim communities.

\footnotetext{
38Sanusi, "Konsep Pembelajaran Fiqh dalam Perspektif Kesehatan Reproduksi," Edukasia: Jurnal Penelitian Pendidikan Islam 10, no. 02 Agustus (2015): 367.

${ }^{39}$ Muh. Nashiruddin, “Fikih Moderat dan Visi Keilmuan Syari'ah di Era Global (Konsep dan Implementasinya pada Fakultas Syari'ah IAIN Surakarta," Jurnal Hukum Diktum 14, no. 01 July (2014): 29.

${ }^{40} \mathrm{M}$. Atho Mudzhar, "Kajian Ilmu-Ilmu Syariáh di Perguruan Tinggi: Sudahkah Merespon Tuntutan Masyarakat?," Asy-Syir'ah; Jurnal Ilmu Syari'ah dan Hukum 46, no. 02 July-December (2016): 369.
} 


\section{Conclusion}

This research results in some following findings: First, the profile of figh munākahah materials in three Madurese Islamic universities are in line with the aim and target of learning, students' need and ability, easy to apply, and in line with respective syllabus materials of each. However, most of references still come from scholars of old jurisprudence schools which tend to use literal perspectives while ignoring contemporary development. Second, the development of figh munäkahah material course occurred through the production of text-books or lecture modules. The lecturers furthermore change the course description at semester learning plan by making proper adjustment to recent social change while mainstreaming gender equality and divorce prevention effort, particularly in explaining some fragile themes on gender injustice. Third, the course materials have not been feasible and well contributing to the divorce prevention particularly because the use of old references which are textually based understanding and not following current legal requirements as well as recent social changes. However, the lecturers balance this by using proper delivery method of learning to introduce students with moderate persepective on figh munākahah.

\section{Bibliography}

Al-Jaziri, Abdurrahman. Al-Figh 'Ala Al-Mazahib Al-Arba'Ah. 4th ed. Beirut: Dar al-Kutub al-Ilmiah, 2003.

Arifin, Imron, ed. Penelitian Kualitatif Dalam Ilmu-Ilmu Social Dan Keagamaan. Malang: Kalimas Sahada, 1997.

Arikunto, Suharsimi. Prosedur Penelitian, Suatu Pendekatan Praktik. Jakarta: Rineka Cipta, 2002.

Decree of Minister of Riset, Technology, and Higher Education in Republic of Indonesia number 2 in 2016 about the amandement of ministerial decree number 26 in 2015 about lecturer's registration in Higher Educational Institute subsection 1 (2016).

Gazali, Rafi'ah. “Tradisi Keilmuan Islam Di Perguruan Tinggi Umum Suatu Tinjauan Di Bidang Hukum Islam Dan Pranata Sosial." Ijtimaiyya 6, no. 1 Pebruary (2013). 
Haq, Ainul. "The Lecturer of Munakahat Fiqh in Islamic Religion and Education Department of Tarbiyah Faculty IAIN Madura, Direct Interview on March 22nd 2018." n.d.

Harian Terbit. “Talaq Divorces.” Mei 29th, 2015.

Ishomuddin. Spektrum Pendidikan Islam. Malang: UMM Press, 1996.

Jalil, Abdul. "The Lecturer of Munakahat Fiqh in the Act of Islamic Family Department Syari'ah Faculty of IAIN Madura, Direct Interview on April 3rd 2018." n.d.

Jasmadi, Chomsin S Widodo and. Panduan Menyusun Bahan Ajar Berbasis Kompetensi. Jakarta: PT Elex Media Kompetindo, 2008.

Jayus, Muhammad. "Menggagas Arah Baru Studi Hukum Islam Di Indonesia." Al-'Adalah XI, no. 02 July (2013).

Lestari, Ika. Pengembangan Bahan Ajar Berbasis Kompetensi. Padang: Akademi Permata, 2013.

Liputan6.com. "Divorce Cases." 17th November, 2016. https://www.liputan6.com/news/read/2654870/224-ribu-istridi-indonesia-ceraikan-suaminya-selama-2016.

Majid, Abdul. Strategi Pembelajaran. Bandung: Remaja Rosdakarya, 2013.

Masyhuri. "The Lecturer of The Act of Marriage Subject Islamic Religion and Education Department of INSTIKA Guluk-Guluk Sumenep, Direct Interview on March 24th 2018." n.d.

Mawardi, Ahmad Farid. "The Lecturer of Munakahat Fiqh in Islamic Religion Faculty of UIM Pamekasan, Direct Interview, May 3rd 2018." n.d.

Moleong, Lexy J. Metode Penelitian Kualitatif. Bandung: Remaja Rosdakarya, 2005.

Mudlofir, Ali. Aplikasi Pengembangan Kurikulum Tingkat Satuan Pendidikan Dan Bahan Ajar Dalam Pendidikan Agama Islam. Jakarta: Rajawali Press, 2011.

Mudzhar, M. Atho. "Kajian Ilmu-Ilmu Syariáh Di Perguruan Tinggi: Sudahkah Merespon Tuntutan Masyarakat?" Asy-Syir'ah Jurnal Ilmu Syari'ah Dan Hukum 46, no. 02 July-December (2016).

Muhammad Ibn Ali al-Hanafi al-Haskafy. Al-Durr Al-Mukhtar. 3rd ed. Beirut: Dar al-Kutub al-Ilmiyyah, n.d.

Nashiruddin, Muh. “Fikih Moderat Dan Visi Keilmuan Syari'ah Di Era Global (Konsep Dan Implementasinya Pada Fakultas Syari'ah IAIN Surakarta." Jurnal Hukum Diktum 14, no. 01 July 
(2014).

Radar Madura. “Talaq Divorce.” May 2th, 2015.

Sanusi. "Konsep Pembelajaran Fiqh Dalam Perspektif Kesehatan Reproduksi." Edukasia: Jurnal Penelitian Pendidikan Islam 10, no. 02 Agustus (2015).

Suleman, Sofyan \& Zulkarnain. Fikih Feminis Menghadirkan Teks Tandingan. Yogyakarta: Pustaka Pelajar, 2014.

Suryabrata, Sumadi. Metodologi Penelitian. Jakarta: Rajawali Press, 1992.

Taylor, Robert Bogdan dan Steven. Dasar-Dasar Penelitian Kualitatif, Terj. A. Khozen Afandi. Surabaya: Usaha Nasional, 1993.

Thoha, Maimun And Muhammad. "Fenomena Cerai Gugat Dan Wacana Kesetaraan Gender (Studi Alasan Di Balik Trend Kasus Cerai Gugat Di Pengadilan Agama Kabupaten Sampang Dan Pamekasan Madura)." Pamekasan, 2017.

Zuhdi, Masyfuk. Masail Al-Diniyah Al-Ijtimaiyah. Jakarta: Gunung Agung, 1993. 